\title{
RACE, RAILWAYS AND DOMICILED EUROPEANS
}

\section{Transforming Cultures eJ ournal, \\ Vol. 3 No 1, February 2008 http:// epress.lib.uts.edu.au/journals/TfC}

\section{Deborah Nixon ${ }^{1}$}

When I asked my father where home was he said, "Oh, wherever the old man was: Bombay, Itarsi, Poona, Nagpur, Bhusawal, Damoh, Jhansi, Jubblepore, Bhopal - there may be more and then I went to boarding school for 9 months of the year."

In thinking about the themes of the conference, landscapes of meaning and transnationalism and diaspora, it is clear in relation to the railway colonies in India that a landscape of meaning was geographically constructed in and around the railways along whichever arterial line one’s family tended to work for. In my father's case it was the Great Indian Peninsula Railway (GIPR) along which are dotted the towns he refers to as 'home'. Bear in her study of Anglo Indians in the railway colony at Kharagpur suggests that the railways represented a desh, 'a home for Anglo Indians wherever they worked was their desh' (2007, p.11).

This is a story about domiciled Europeans and Anglo Indians, many of whom left postcolonial India after partition, scattering and settling in the UK or the USA, Australia, Canada (Blunt 2003, p.283). It is also the story of my father, Leslie Nixon.

This paper represents a preliminary exploration of the context from which his story emerged and suggests what place and ethnicity meant to domiciled Europeans and to Anglo Indians in late colonial India up to the partition and independence in 1947. Partition represents a point at which many people in India were forced to make a decision about where they would live; for domiciled Europeans and Anglo Indians it was a time when they had to decide whether to stay or whether to migrate. Reasons for migration were varied and for Anglo Indians the process was staggered over several

\footnotetext{
${ }^{1}$ Deborah Nixon is a PhD scholar at the University of Technology Sydney.
} 
decades. For many families, whether Europeans domiciled in India with familial ties stretching back for generations or Anglo Indians in a similar situation, the decision must have been difficult, but with the violence and chaos that accompanied the partition in various parts of India, the decision for some was unequivocal. It also meant that despite identifying themselves as European or British and having never lived or even visited Europe, people from both communities had to confront the notion of where home was going to be. Sometimes home was not what was expected. One of my interviewees commented that part of his family went to the UK but returned to India because they were considered 'too swarthy'. Anglo Indians constitute a group for whom 'locating a sense of identity and a place to call home have been key concerns' (Blunt 2003, p. 282). Anglo Indians deferred to the West culturally in terms of food, dress and language but were often ridiculed for making this alignment (Blunt 2003, p.285). The tension that existed between those identified as Anglo Indian and those identified as Domiciled European may have resulted from 'maintaining social distinctions amongst themselves' (Anderson cited in Stoler 1989, p.137). The racialised nature of employment within the railways may also have played a large part in creating this unease.

domiciled Europeans and Anglo Indians had been employed to a large extent by the railways and the telegraph services, however I would like to focus on attitudes towards the railway colonies and the 'peculiar' position of domiciled Europeans living in them. According to Arnold (1980 p.236) 'out of four million industrial workers in India in the 1920s 900,000 worked for the railroads' making the railroads one of the biggest employers of 'industrial labor'. Arnold comments further that within that workforce there was racial tension that often erupted into violence. However, the number of domiciled Europeans and Anglo Indians employed by the railways began to decline in the 1920s as a result of the Montagu-Chelmsford Act passed in 1919, which led to Indianisation of the workforce and the influx of superior European staff from outside India' (Arnold 1980, p.252). The railways were also hotbeds of industrial unrest because of the inequitable treatment of employees. Arnold (1980) reports that racial conflict was a feature of colonial industrial labour management. From 1861 the 'pure' European population was replaced with domiciled Europeans and Anglo Indians and Indians. Between 1908 and 1928 numerous strikes by Indian workers took place to protest against the racial employment hierarchy (Bear 1994, p. 543). 
Railway communities were both a source of employment and a social crucible for preserving a particular kind of British culture and social position predicated on notions of race, caste and hierarchy. Indeed, as commented upon by McMenamin the class hierarchy in British society found parallels in the Indian caste system linking race and colour together and according certain privileges to groups based on this differentiation (2001, p. 121). The railway communities were not homogenous - they included people from a variety of European and Indian backgrounds. Caplan (1995) explains in his study of the railway colony in Madras, that it was comprised of people described as Anglo Indian who could have been the descendents of Portuguese, French or Dutch forebears. In addition the use of the word community conjures an idea of a whole but as Carton points out just the name Anglo Indian 'has been an area of contestation that reflected the diversity and multiplicity of the Eurasian condition' (2000, p. 1). Despite the lack of precise figures even the so called British community was diverse, dominated by the number of Scots and Irish rather than English (Marshall 1997, p.91).

The interviews conducted for this study were approximately an hour long and although they were structured around a set of questions I allowed them to proceed as informally as possible. The interviewees I have spoken to come from a variety of Anglo Indian backgrounds. Robert, Lois Harding, Stan Blackford and Des Tellis refer to themselves as Anglo Indian but between them they include German, Scottish, Portuguese, English and Irish forebears. For the Anglo Indians these forebears represent the male side of their ancestry, their mothers were all of indeterminate Indian descent. Leslie's mother was born in the UK of Irish descent but his father was born in India and so were his grandparents. It is known that they were married in Bombay in 1882 but as the maternal line was not recorded their ancestry remains a mystery. All the interviewees were born and educated in India.

My father was part of a Domiciled European railway family of at least 5 generations in India. What emerged from my interviews with Leslie Nixon despite the temporal and geographical distance of nearly 60 years of living in Australia is still a desire to differentiate himself from the Anglo Indian community. When talking about his early life in India he identifies strongly with his maternal British ancestry and had never heard the term Domiciled European before I used it. On the other hand all the Anglo Indian interviewees were familiar with the term. Stan Blackford referred to it rather 
disparagingly as a way of big noting oneself of "showing superiority and it means I'm fairer that you". In a biographical account of growing up in India, McGready -Buffardi comments that British born residents looked down on Indian born British residents (domiciled Europeans) who considered themselves a 'cut above mixed breed Anglo Indians' (2004, p.56). Remarks such as these indicate that there was an element of tension between the communities and that there were in reality economic as well as social reasons that underlay this complicated relationship. In turn domiciled Europeans, according to Arnold, were themselves looked upon as 'lowly in sight of the white elite ...' (1980 p.252).

Despite the fact that the railways provided an important method of administering the Empire and were a major employer there was a certain negative stigma attached to working within it. Caplan (2001) notes that 'hierarchies based on distinctions of European descent arose within the Eurasian population' and that the 'railways and the telegraph were reserved for the employment of Eurasians and (non-elite Europeans) who were deemed more trustworthy than the natives’ (2001 pp.746-747). Lois Harding commented that she had no idea that 'railway people were considered to be the lowest of the low on the social scale which I was surprised about because I thought we did a really good job'. In addition she thought it unfair that those who came from England who may have had a lower level of literacy and education were entitled to better positions and pay -'because they were English they were given the higher jobs.' (Interview, Adelaide 2006)

The attitude towards people employed in the railways as being inferior is again expressed on a biographical website of growing up in India:

... when the subject of Railways was mentioned there seemed to be an antipathy towards 'those Railway people'. I found this somewhat mysterious and puzzling : however, not being in contact with any of the Railway Colony; they lived in the extreme north of Delhi and we were housed in the south or 'Posh' area as some saw it. I also remember being told to stay clear of the area where they lived. 
Railway people were considered a bit 'Racy' and not quite up to the mark or shall we say a bit common. In much later days I was to discover for myself that these opinions were positively unfair and rather, or downright ignorant (Alton-Price 2007).

My father says that he thinks that his family were middle class, certainly they had all the trappings in terms of servants, large houses and private schools but the difference was that this all happened in India. They were not educated in England nor did they make frequent trips back to top up their Britishness. Mitzutani, when discussing themes of inclusion and exclusion in colonial historiography, argues that what separated 'domicile from non domicile' were the 'social and economic hierarchies that structured British society' (2002, p.17). The middle class separated themselves through a form of snobbishness and to 'remain white meant to remain connected to the imperial metropole’ which was for many railway families economically impossible (Mitzutani 2002, p.17).

Younger (1984) credits the railways and the telegraph services as two sources of employment that saved the community from financial ruin. In addition from 1857 railway colonies were built to accommodate employees and their families and by the 1930s according to Bear (1994) virtually all upper subordinate positions were occupied by Anglo Indians and domiciled Europeans. Bear (1994) argues that these colonies acted as sites to stem the miscegenation of European culture through remaining closed; having their own institutes for dances and socialising, their own schools and their own domestic arrangements as far as housing and servants quarters were concerned.

Bear sees the railway colonies as sites that "constructed and contested European identity" (1994, p.531) they were a heterotopia characterised by being intrinsically connected to the wider community and yet separated by an active form of gate keeping and organised into a hierarchy predicated on racial fitness for command. Heterotopias 'presuppose a system of opening and closing that both isolates them and makes them penetrable”(Foucault 1967). A heterotopia reflects the structure of the wider space it is situated in according to Foucault - in this case not the wider Indian community but space created by the 'pure' British in India. So the railways may have provided an alternative heterotopic space constructed to enact a hyperbolic of the dominant culture. 
Within this closed but open space was a hierarchy predicated on race where higher positions were reserved for those with more 'European blood' who were deemed more suitable for control of the modernising force of the railways. It was 'an elaborate moral typography of racial fitness for command' (Bear 1994, p. 535). Arnold (1980, p.252) concurs with this description of the organization within the railways commenting that 'these European and Eurasian subordinates enjoyed (and jealously preserved) a privileged position as a racially defined aristocracy of labor'. However, the number of Indians working on the railways (albeit in subordinate positions) always outnumbered the Domiciled European and Anglo Indian employees.

The Domiciled European community and in particular the Anglo Indian communities are often described as being liminal, interstitial or marginal. As Stoler argues colonies presented 'new constructions of European-ness and that colonial boundaries were never clear rather colonizers lived in 'imagined communities' (1989, p.137). The assumption here is that there was a porous or blurry boundary of some kind drawn between these communities through which people could slip according to the lightness of their skin colour and their paternity. Carton $(1989$, p. 6) suggests that there was a 'fundamental racial boundary between the two communities' which in reality was often subverted by people moving across the boundary. McMenamin (2001, p.119) has interviewed domiciled Europeans in New Zealand two of her participants were from railway families and commented that they 'mixed exclusively with other domiciled Europeans only occasionally with Anglo Indians' and rarely if at all with the local Indian families. Leslie also said he never played with Anglo Indians and never really knew any Indian children as his stepmother tried to keep the family away from the children of their servants, or later never had an Anglo Indian girlfriend. However, in looking at family photographs I found certain dissonances appearing in Leslie's narrative that indicated a lot more contact with the Anglo Indian community than he suggests.

In talking about his background what emerged from the interviews about his idea of social position was a very strong sense of his wanting to identify with British culture and distance himself from the Anglo Indian or mixed blood community. He often refers to his grandmother's Irish heritage but does not know where she was born and until I went to India and found her grave he did not know that she had died in Bhusuwal and was buried alongside his mother. 
Leslie had never heard the term 'domiciled European' before the interviews and describes himself as British. Indeed many Anglo Indians are of the opinion that this term was used by people who wanted to distance themselves from Anglo Indians and gain status on the social scale. McMenamin points out that the term Anglo Indian overshadowed 'the marked social gradations amongst domiciled Europeans and Anglo Indians' (2001 p. 110). It was not difficult to hide one’s origins if one’s family were light skinned and both Anglo Indians and domiciled Europeans could claim to be European based on the racial descent of their fathers (Anthony 1969, p5). It is generally agreed that a Domiciled European was a person born in India of parents identified as European or British who were 'permanently' settled in India even though India was never intended to be a permanent settler colony - domiciled Europeans never officially migrated to India. As early as the 1891 census Baines (cited in Friedlander 2002) identifies the groups as: Europeans of British descent born and permanently domiciled in India and the Eurasians. The place occupied by Anglo Indians is referred to as 'peculiar' in the 1911 census (1911 p22)! Indeed the census reports are interesting documents constantly referring to their own unreliability because of the tendency for people to return themselves as European or British and for census officials to 'correct' the data.

Despite these ambiguous definitions and the added confusion of dual status which affected Anglo Indians many authors argue that the construction of race in India was not based on 'blood' alone but on a mix of religion, accent, place of birth and schooling, employment and the financial ability to remain transient for example, frequent trips back to Britain for the purposes of education or employment. Initially those born of a British father could claim to be British and everybody domiciled in India was referred to as Anglo Indian but the communities began to distinguish between themselves along racial lines in 1911 when the census indicated that it included those of mixed parentage. This distinction was always problematic (because it was not entirely based on genetics) and as Buettner points out, domiciled Europeans were commonly equated with the racially mixed by the colonial elites (2004, p81). It was a cultural and social identification.

Hence, British Indians the 'real' British were not born in India but initially came out on covenanted contacts (fixed term contracts) and generally sent their children back to 
Britain to be educated. Even if parents themselves were born in India it seems to have been preferable to send children to the mountains to schools like St George's College than to have them at home in closer contact with the wider community.

Despite notions of neutrality about their own racial identity the British in India were constantly trying to guard against trangressions of the boundaries they set up in the census reports. The census reports attest to this bureaucratic attempt to fix the groups along lines which, according to various accounts, were porous and challenged by domiciled Europeans, Anglo Indians and Christian Indians as members from each group attempted to avail themselves of the privileges (principally employment) attached to each level in the hierarchy. At the same time there are comments in the reports about their unreliability. Friedlander's analysis of census reports is based on data from the 1881 and 1901 reports and suggests that 'typology of race, classifying races and communities, was a major project of the British in India in the $19^{\text {th }}$ century and $\ldots$ comes out in the census reports' (2002, p.9). He also points out that colonial officials were not above fiddling the books to fit into what they considered to be their version of the world, for example that Anglo Indians /Eurasians must be Christian so would not tolerate anything else and 'corrected' the entries that did not conform (ibid. p.10). According to Caplan (2001) Indians describing themselves as Christian were also attempting to jump the race boundary and be classified as Anglo Indian. This anxiety over racial categories was a very real concern because it had a direct affect on the kind of employment and the level in the hierarchy Anglo Indians and domiciled Europeans could aspire to within their place of employ.

In addition to census officials fiddling the books, the Anglo Indian population itself was also being misrepresented, as is remarked upon in the 1921 census: 'The actual figures of Europeans and of the Anglo -Indian "Domiciled Community” are always somewhat doubtful owing to the tendency of the latter to return themselves as European and of Indian Christians to claim to be Anglo Indians' (Census of India 1921, p.231). Later on in the 1930s and 1940s Sir Henry Gidney and Frank Anthony, early leaders of the AI community in India both suggested the figures were out of touch with reality because of the number of people who claimed to be European when in fact they may have had mixed 'blood'. Gidney suggests that the figures were out by 40,000 in 1931 and Anthony suggests that in 1941 the figures were out by about 30,000. The 1931 census 
official noted that the there was a tendency to return oneself as European depending on skin colour and that at least 30,000 could be deducted from the number of Europeans (Buettner 2000, p.281). Anthony remained doubtful over European claims to racial purity commenting that, ' European families (particularly those of 3-4 generations) rarely escaped the Anglo Indian tarbrush’ (1969, p.5). Both leaders wanted Anglo Indians to claim their mixed ancestry and to be accurately counted and properly represented in the legislature. According to Moore in the 'Anglo Indian vision' there was an element of choice attached to how one positioned oneself and this relied on skin colour which became a dilemma when one member of the family looked suspiciously like an India forebear. This choice is sometimes referred to as 'passing': in other words depending on skin colour an Anglo Indian could pass her/himself off as European. To add to that (because of dual status) Anglo Indians were designated Indian for defence and for employment "statutory natives of India". The census reports indicate that despite efforts to classify mixed European and the domiciled population it was virtually impossible to rely on the figures for a clear picture of the racial profile of the European and mixed race population.

The railway communities were highly transient in nature as employees were moved along the lines to which they were attached as the need arose through promotion.

When I asked my father where home was he responded, 'Oh wherever the old man was: Bombay, Itarsi, Poona, Nagpur, Bhusawal ,Damoh, Jhansi, Jubblepore, Bhopal there may be more and then I went to boarding school for 9 months of the year.' For domiciled Europeans and Anglo Indian children, particularly those from the railways, schools were far from the family usually in the foothills of the Himalayas. School for Leslie, Robert, Lois’ brother and Des was at St Georges near Mussoorie. Lois went to Oak Grove, 'a school for children whose parents were on the railways and needed to get away from the heat of the plains'. All interviewees remarked on the trauma of being separated from their families. Lois commented that on the way up to Mussoorie on seeing 'the thin dark line of these huge mountains I'd feel sick in my stomach straight away'. Similarly Leslie recalled feeling at the age of seven, 'bloody terrified all the time going up there'. His brother later commented to me that, 'it was like being in Alcatraz'. Robert and Des said they loved being at school but that although the discipline was very strict they needed it and 'probably deserved the punishments' they received. Stan went 
to a variety of schools and suffered from being bullied and felt like a 'misfit' until he arrived through a series of schools at St Joseph’s College, North Point.

The detachment that resulted from having an itinerant home seems to have had an impact on a sense of belonging to any place in India despite being the product of generations domiciled there. Although he says he was British he never lived in the UK for any significant length of time. Still Britain remained to many a mythologised place, not a real home to identify with but in the sense of it being a cultural home. Anglo Indians lived in a colonial diaspora within India and a post colonial diaspora after Independence (Blunt 2003).

My father has never actively sought out any other people from his school even though I met two Anglo Indians in Adelaide from his school who seemed to know of his existence - they were active in the Anglo Indian community - members of old school boy's clubs contributing to news letters etc. I think the impact of partition on those that served in the army combined with a very set notion of social superiority and his 'Britishness' has driven away a desire for contact that could be confronting or serve to revive uncomfortable memories of the his last experience of India.

\section{The Photos}

Photographs taken of my grandfather and the family in the railway colonies and in private life are evidence that the boundaries that are said to have existed between people in the railways articulated in the research literature official reports and interviews were extremely ambiguous. Photos give a glimpse of quotidian life that says volumes about the way people negotiated their way through this complex racially stratified world.

During the interviews Leslie was reluctant to admit to any social interaction with Anglo Indians or Indians communities and emphasised his social distance from them.

However, going through family photos taken in India prior to 1947 I was struck by the dissonances in the way my father presented his story and what was evidenced in the photos. These showed there was a significant and constant amount of contact with Anglo Indians in all spheres of social life from school life and shikar (hunting trips) to the existence of an adopted Anglo Indian 'brother' Hussein Amin (Hussein Amin 
anglicised his name to Gordon Forbes). Hussein Amin was wanted neither by his Scottish mother nor his Indian father who happened to be a friend of my grandfather. Gordon Forbes' father had taken a second wife causing his European wife to leave him. It was decided by my grandfather that Gordon Forbes would live with the family and go to St George's with my father and his brothers. It was only after noticing him in the picture below that my father related the story to me and commented that Gordon Forbes was 'like one of us, although I always called him Hussein”.

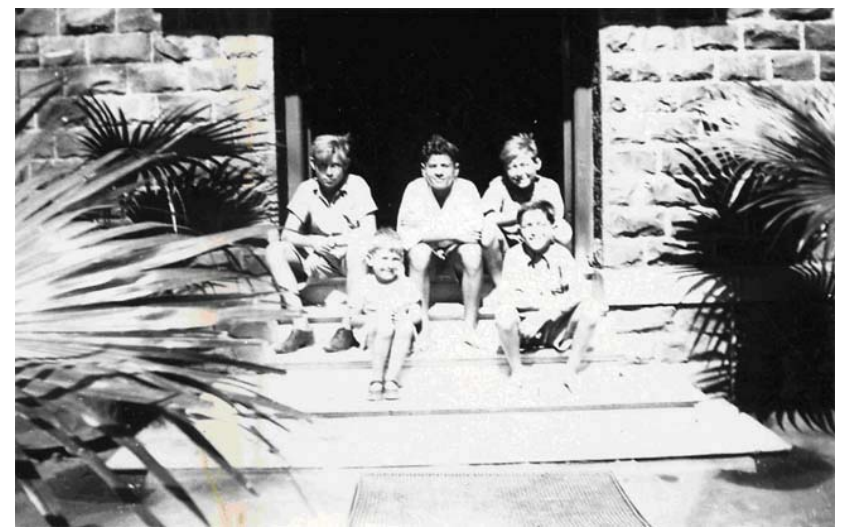

Hussein sits in between 'bothers' on the top row.

School photos show Leslie sitting amongst a group of Anglo Indian students with only one conspicuously looking European student. He also qualified that the school he went to was the best in India because members of the Tatas (a very wealthy Parsee family) and several Indian Princess went to the same school. And that he was in constant competition with 'Jimmy Moore, a little but very smart bloke'.

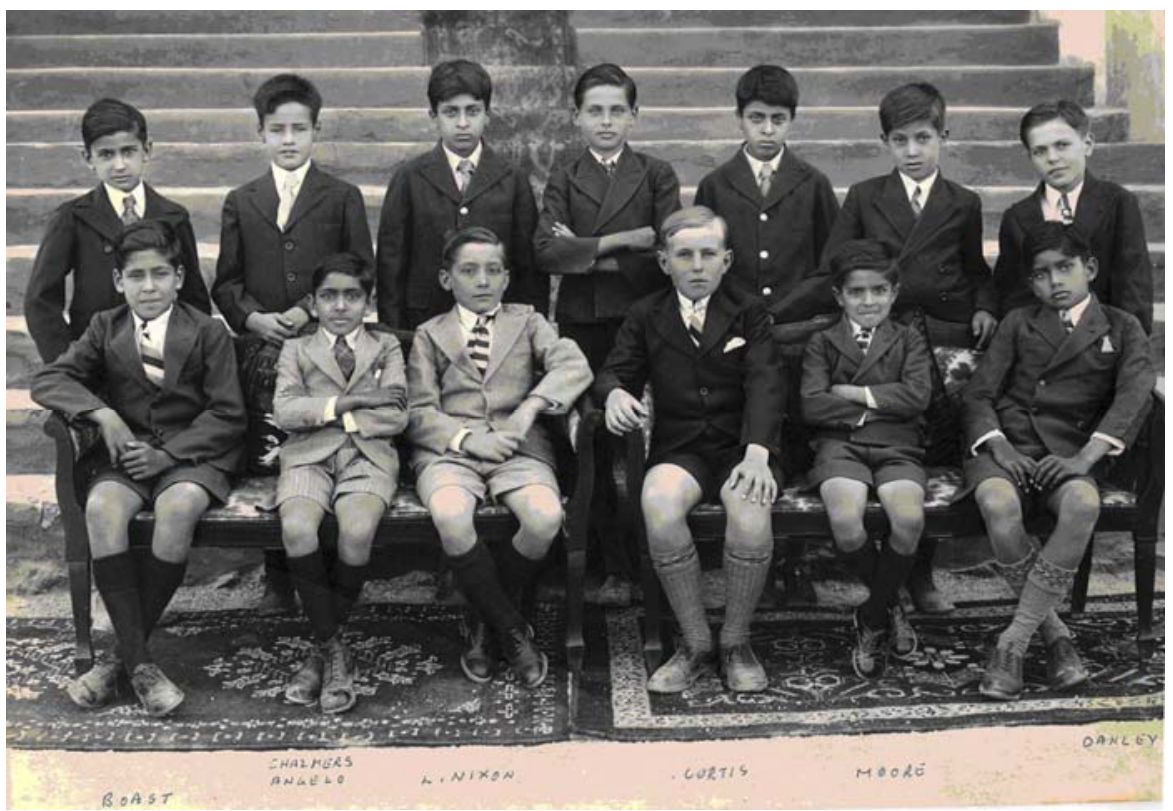


Leslie denied having any Anglo Indian girlfriends and yet his album is littered with pictures of attractive young Anglo Indian women at dances, on trains and casually leaning against historic monuments!! When pressed to remember who these people were, he and retreats behind his memory lapses and it is difficult to uncover anymore information.

A rather grim looking grandmother features in several pictures taken in studios set up to look like they were taken in an English country garden.

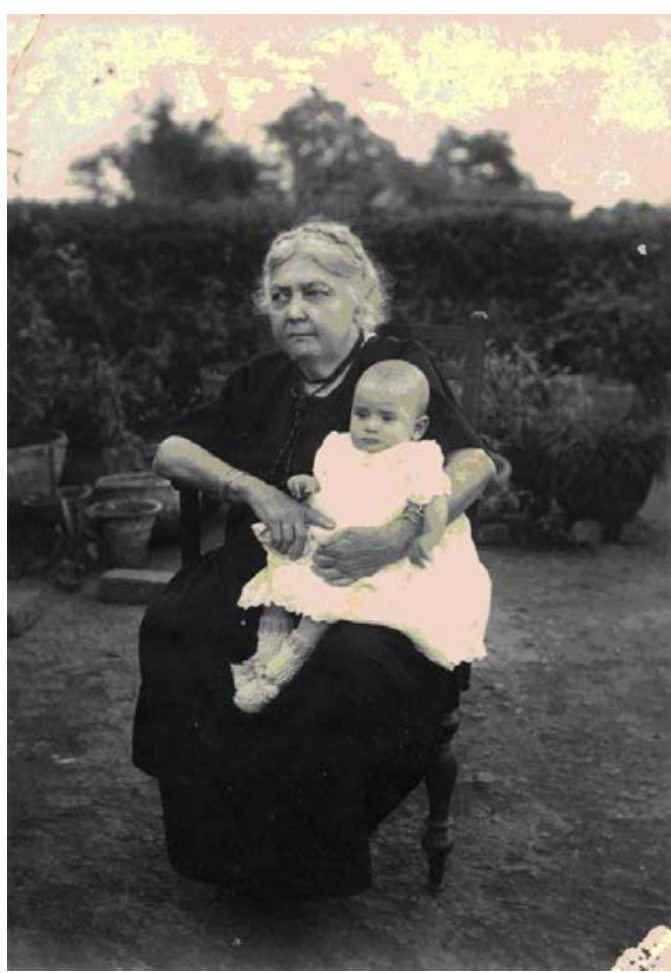

Garden in Bhusawal

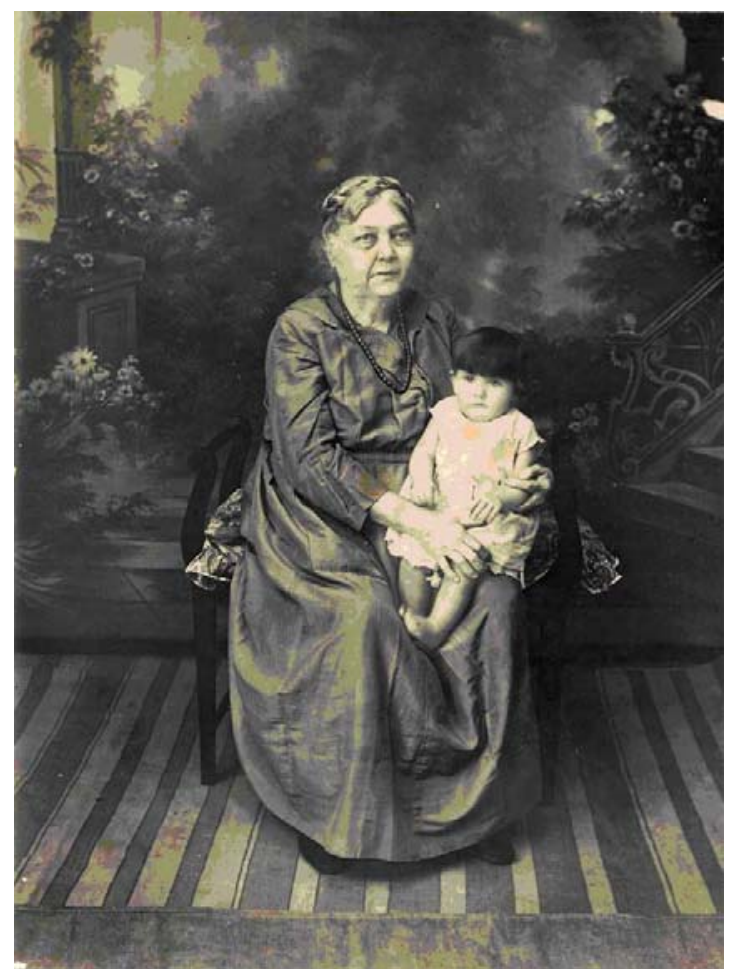

Studio Jhansi

There is very little in these photos to suggest that they were taken thousands of miles from anything resembling such a location. Even the outdoor photos taken in the railway accommodation garden offer few clues as to where they actually are. It is interesting to note that the garden is virtually all contained in pots for easy transportation to the next 'home' along the railway line. Travelling to one of the towns where the family lived in (Bhusuwal in Maharashtra ) I visited the area known as 40 blocks where the railway colony housing would have been. Through the notes scribbled onto the backs of photos I was able to identify what may have been the family home and locate the cemetery where my grandmother and great grandmother were buried. It was also through contacting one of the last Anglo Indian families still living in Bhusawal that I was able 
to gain access to the railway offices and see the names of the loco foremen listed on a wooden noticeboard. I recognised, with a sense of excitement, my grandfather's name. I was taken to the Limpus club now empty but once a hub of activity as the Anglo Indian and European Social club. My Grandfather was the vice president for several years, so his name also appeared here on an honour board in gold letters.

In several photographs of my grandparents in their official capacity, the formally posed photos taken in railway towns with staff illustrate a kind of ordering, a fanning out from the centre where the seated figures appear to be both Domiciled European and Anglo Indian. In other more relaxed photos with the Alvarez family my grandfather is often off centre or standing behind someone as if he wanted to fade into the background. I imagine that the positioning of people also indicated some kind of ranking as photographs were carefully choreographed encoding messages about rank and class. Family photographs are more than just souvenirs of anniversaries and family gatherings. In addition, as Lalvani (1996 p63) puts it, 'they.... affirm and celebrate particular discursive and ideological formations .... it is a metonymic performance of a discursive field...' and the body becomes a signifier of class 'in a society increasingly mediated by visual interaction' (ibid. p43).

There is no written indication on the photo below of where it was taken. My grandfather, who may have been highest in rank as a loco-foreman, sits in the centre of the photo.

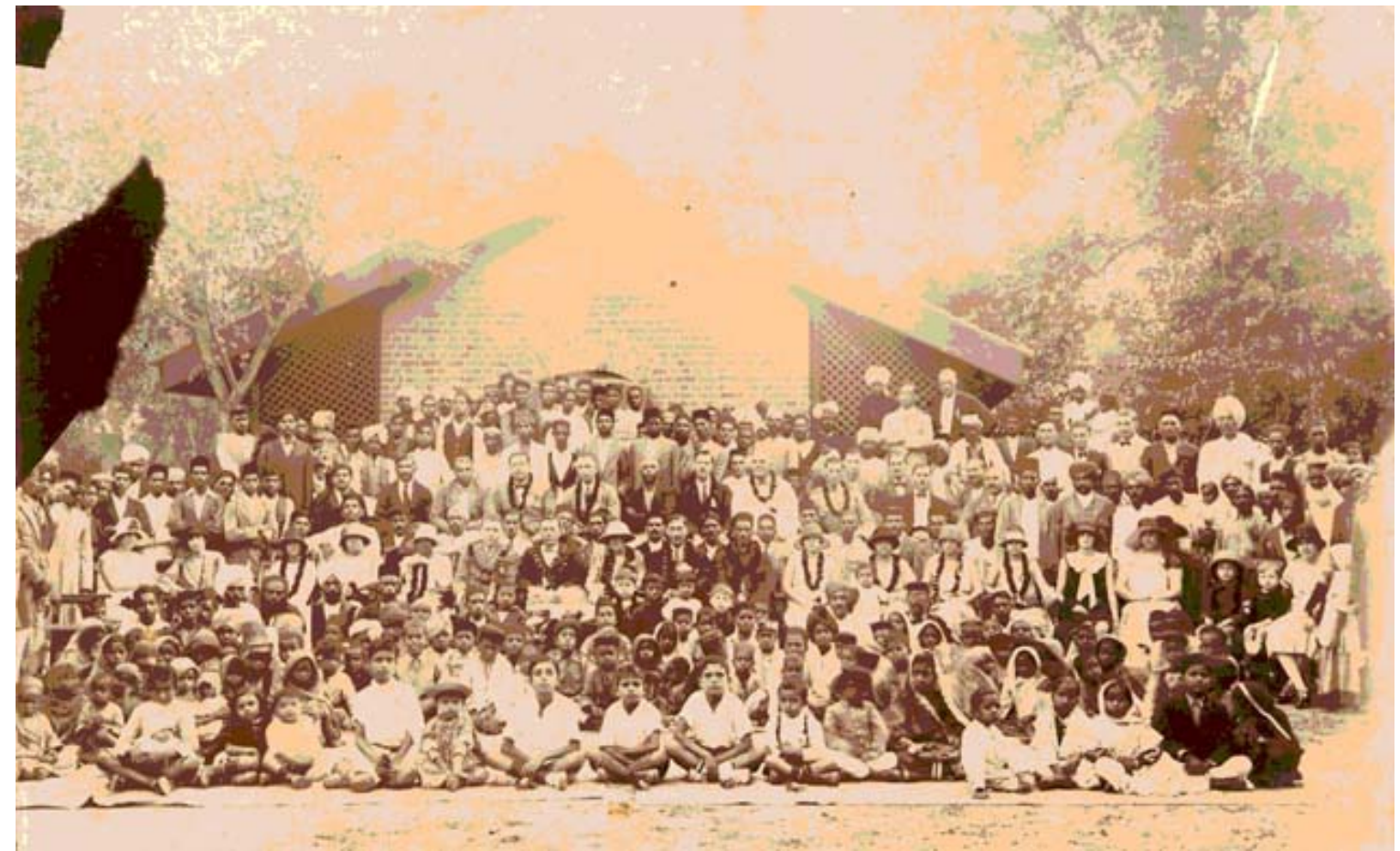


The photograph below was taken at Damoh in 1924 it really appeals to me because it seems like everyone in the photo imagines the picture being taken is of them alone. The group seems relaxed, the smiles look spontaneous and everybody is striking a different pose as if they have not been told to stand or sit in particular way. There appears to be a real sense of ease and contact here. It might be a social club meeting the people in the photo look to be both Anglo Indian, Indian and European. The faces are looking directly into the camera and I can see that my grandmother (seated in the centre) is smiling as is the young girl to her left.
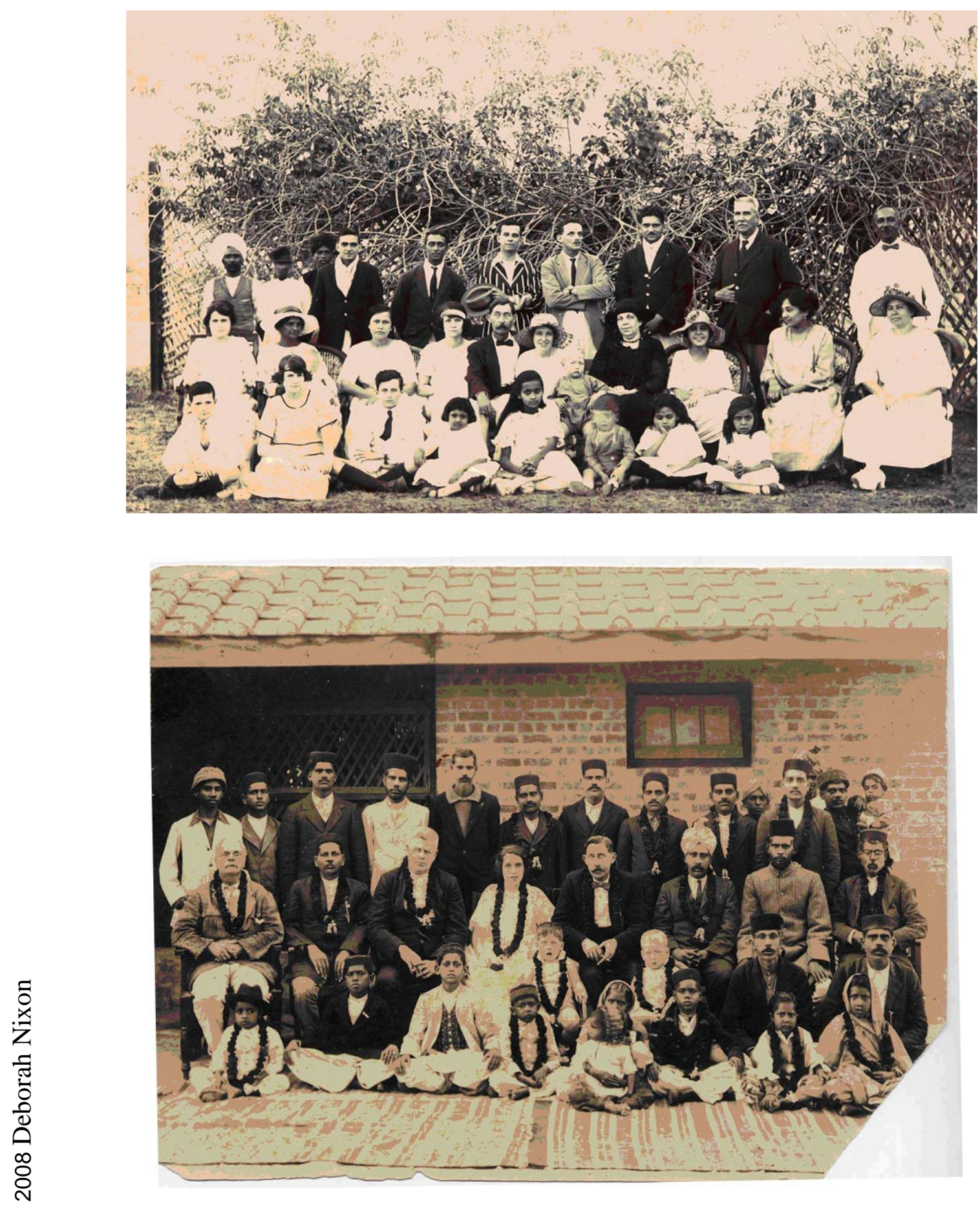
The above photo was taken at Jhansi in 1923, however, in contrast to the first photo it is more formal and shows Indian and possibly British and domiciled European workers. Again my grandfather and grandmother sit in the centre of the photo. Although I cannot generalise from the few photos included here the number of Europeans may reflect the fact that there were fewer Anglo Indians and Europeans working in the railways by this stage.

When confronted by the contradictions in the photos and his own descriptions of no social contact with Anglo Indians my father tends to dismiss these photos as one offs as outside what usually went on. He says the Alvarez family were only friends because 'Alvarez was a doctor and my father was a hypochondriac'. However, I believe there was a real friendship there and that my grandfather had much more to do with Anglo Indians than my father will admit to. In addition I have recently found out that my uncle’s middle name was taken from Costanzio Alvarez.

Never making contact with the Anglo Indian community in Adelaide and vehemently defending his Britishness helped Leslie to maintain the social distance he practiced in India. In contrast to this his father looks from the photos to be a man at ease in his world with Anglo Indian friends and the compassion to adopt Hussein Amin. According to an Australian Gurkha (Rob May) I interviewed, my grandfather was not a 'dyed in the wool Pom and he had an Anglo Banglo accent... you've got a touch of the tarbrush but don't tell Nick I said that.” The picture below shows my father (right) the Australian Gurkha Rob May and my grandfather (left) about to go hunting.

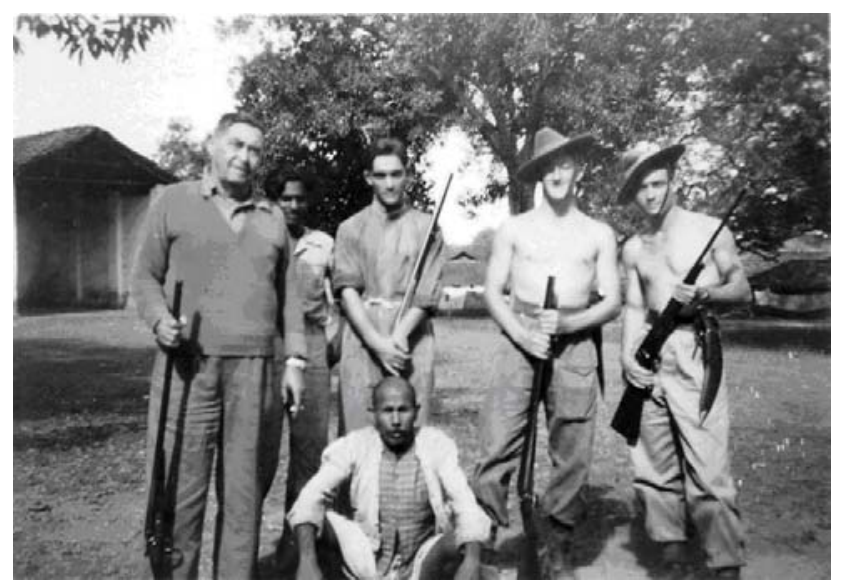

Christmas 1946 Pagdhal.

From left, Bernard Nixon, Norman Costanzio Nixon, Robert May, Leslie Nixon. 
What I also see in all these pictures is a tenuous link with the past between memory and experience: a life de-contextualised, peeping out of a dead colonial past. It cannot be taken as the 'truth' about the way people lived but neither is the spoken word. What they can do is offer opportunities for multiple 'readings'. Combined, it is possible to stitch together the membrane of a narrative about the way people lived.

There are no photos of the partition itself. That is, the migration kafilas and slaughters. There are only pictures taken in training camps and off duty on leave. My father said as soldiers they were not allowed to take pictures and commented that he would not have wanted to photograph the things he saw 'the Indians doing to one another'. He has never wanted return to India.

What I found through this preliminary exploration was that the landscape of meaning for domiciled Europeans and Anglo Indians was often not in the place where they lived but in a place they longed to go to and be accepted in, less in a geographical than a social and cultural sense. The complex arrangement of people and their families within the railway colonies according to their ethnicity which was either imposed on them as a category by the colonial government or decided by themselves must have caused a degree of tension between the communities which led in some cases to a wish to disassociate with that life altogether.

In the end I think the place where my father finally found his home was in the heart of his family.

\section{Bibliography}

Alton-Price, J. (n.d.), Railways Colonies in India, viewed $10^{\text {th }}$ April 2007 $<$ www.pricewebhome.co.uk/index.htm>

Anthony F (1969) Britain's Betrayal In India; the story of the Anglo India community, Allied Publishers, Bombay.

Arnold, D. (1980) "Industrial Violence in Colonial India”, Comparative Studies in Society and History, vol. 22 (22) April, pp. 234-255.

Bear, L.G. (1994) "Miscegenations of Modernity: constructing European respectability and race in the Indian railway colony, 1857-1931", Women's History Review, vol. 3 (4): 531-548. 
Bear, L. (2007) Lines of the Nation: Indian Railway Workers, Bureaucracy, and the Intimate Historical Self , Columbia University Press, New York.

Blunt, A. (2003) Geographies of Diaspora and mixed descent: Anglo Indians in India and Britain, International Journal of Population Geography, vol. 9 (4) July, pp. 281-294.

Buettner, E. (2004) Empire Families: Britons in Late Imperial India Oxford University Press, Oxford.

Buettner, E. (2000) Problematic Spaces, Problematic Races: defining Europeans in late colonial India, Women's History Review, vol.9 (2): 277-298.

Butalia, U. (1998) The Other Side of Silence, Penguin Books, India.

Caplan, L. (2001) Children of Colonialism: Anglo-Indians in a Postcolonial World, Berg, Oxford.

Caplan, L. (1995) "Creole world, purist rhetoric: Anglo-Indian cultural debates in colonial and contemporary Madras", The Journal of The Royal Anthropological Institute, University of London, vol. 1 (4):743-762.

Carton D. (2000) "Beyond "Cotton Mary": Anglo Indian categories and reclaiming the diverse past”, International Journal of Anglo-Indian Studies, vol. 5 (1): 1-12.

Cressey, P.F. (1935) “The Anglo Indians: A disorganized marginal group”, Social Forces, vol 14 (2) December pp. 363-268.

Foucault, M. (1967) “Of Other Spaces: Heterotopias, 'Des Espace Autres”” Architecture movementContinuitAin October, 1984:

$<$ www.foucault.info/documents/heteroTopia/>

Friedlander, P. (2002) Religion Race, Language and the Anglo Indians: Eurasians in the census of British India, La Trobe University, viewed on 12 November 2007, $<$ www.chef.lib.latrobe.edu.au/dcd/Anglo-Indian>.

Government of India (1921) Census of India,1, Part 1.

Hedin, E.L. (1934) “The Anglo Indian Community”, The American Journal Of Sociology, vol. 40 (2) September, pp. 165 - 179.

Lalvani, S. (1996) Photography, Vision, and the Production of Modern Bodies, SUNY, New York.

Marshall P J. (1997) "British Society in India under the East India Company", Modern Asian Studies, Vol 3 (1).

McGready-Buffardy P. (2006) Hearts Divided by the Raj, Authorhouse, USA.

McMenamin, D. (2001) "Identifying domiciled Europeans in Colonial India: Poor Whites or Privileged Community?”, New Zealand Journal of Asian Studies, vol.3 (1):106-127.

McMenamin, D. (2005) “The curious exclusion of Anglo Indians from mass slaughter during the partition of India”, Journal of Anglo Indian Studies, no.16, available online: <http://home.alphalink.com.au/ agilbert/jed_16.html>

Mitzutani, S. (2002) "Rethinking inclusion and exclusion: the question of mixed-race presence in late colonial India", University of Sussex Journal of Contemporary History, Issue 5, December, pp,1-16. 
Stoler, A.L. (1989) "Rethinking colonial categories: European communities and the boundaries of rule”, Comparative Studies in Society and History, vol. 13 (1), January, pp.134-160.

Younger, C. (1984) Anglo Indians from 1919-1983: imges of a community in transition, $\mathrm{PhD}$ thesis, University of Sydney, Sydney.

Interviewees - tapes held by Deborah Nixon UTS

Stan Blackford, Interviewed Adelaide, February $18^{\text {th }} 2006$

Lois Harding, Interviewed Adelaide, February $19^{\text {th }} 2006$

Rob May, Interviewed Perth, July $18^{\text {th }} 2006$

Robert Nicholls, Interviewed Adelaide, February $18^{\text {th }} 2006$

Leslie Nixon, Interviewed Adelaide, $5^{\text {th }}$ May 2005

Desmond Tellis, Interviewed Adelaide, $18^{\text {th }}$ February 2006 